materials as coherent works, themed collections or virtual exhibits. Linked open data models are increasingly used by libraries, archives and museums to provide access to their catalogues and digitised collections using Open Web Platform standards developed by the World Wide Web Consortium. The final product would be a dynamic system that would allow the user to enter the search term 'cholera' and view all sources without leaving the platform. Historians would be encouraged to expand the audience of their published work by curating themed exhibits that would seamlessly present a brief synopsis of their argument and a basic narrative interspersed with medical reports, photographs and clickable links to the bibliography. Essentially, this would be an endlessly expandable online medical history museum, and once the model has been created for the Chinese material, further funding and collaborations would lead to projects on other parts of the world. With such expansion and its inherent ease of use, the new digital platform could become a point of contact between historians, clinical researchers and even enlightened policy makers.

In the meantime, the resource portal has seen significant use since its launch in 2013, with an average of over seven hundred page views per month in 2014 and 2015 - about half from the US and one-third from China and Hong Kong. As a general rule, most digitised sources available here are in English, as are physical sources described in North American and British archives, while those in China are in Chinese. The website layout was designed for simplicity of appearance and use on computers, tablets or mobile phones, by Aaron Ganci of the Herron School of Art and Design at IUPUI. Given the predominance of English language sources, it will be also be a useful tool for historians of medicine in other parts of the world seeking to write more balanced accounts of the history of disease and human responses to it.

David Luesink

University of Pittsburgh, USA

doi:10.1017/mdh.2016.86

\title{
Review of Setouchi International Art Festival/Setouchi Triennale 2016
}

Hansen's disease, as survivors prefer to call the illness known more pejoratively as leprosy, has a history that is deeply connected to its visibility. Scholars such as Zachary Gussow have connected the visibility of the disease and the disfigurements it causes to discrimination against those who suffer from the illness. ${ }^{1}$ Indeed, the visibility of the illness has meant that bodies affected by Hansen's disease, abject as they are, have long been objects of public display, consumption and metaphor-making. As an example, Christine E. Boeckl, in her work Images of Leprosy: Disease, Religion, and Politics in European Art, has traced the political theology of Hansen's disease sufferers in western art from the fourth century $\mathrm{AD}$, arguing that, historically, the depiction of the body of the afflicted was used as a metaphor for political problems and social messages. ${ }^{2}$

\footnotetext{
${ }^{1}$ Z. Gussow, Leprosy, Racism, and Public Health: Social Policy in Chronic Disease Control (Westview Press, 1989).

${ }^{2}$ C. M. Boeckl, Images of Leprosy: Disease, Religion, and Politics in European Art (Truman State University Press, 2011).
} 
Thus, the biopolitics of the artistic representation of sufferers of Hansen's disease has always been a part of the illness. In the nineteenth and early twentieth centuries, artistic depictions expanded to include medical representations as the disease was legally and medically targeted. Legislation aimed at Hansen's disease and allowing for the quarantine of sufferers was passed in 1907 and 1931. The first quarantine hospital opened in 1909, and, from the first, museums attached to Hansen's disease quarantine facilities in Japan documented the fragmented bodies of sufferers, reducing the illness experience to hands, ears and flesh teeming with bacilli. In the 1920s and 1930s, hospitals, laboratories and medical museums were open for medical and relief work tours. Bodies of Hansen's disease sufferers were put on display to reinforce the idea that medical science had the ability to contain and control biological threats. ${ }^{3}$

Legally, quarantine was not abolished until 1996, although the enforcement of the policy had always been fluid. ${ }^{4}$ After the disease became curable in Japan in the late 1940s, survivors of Hansen's disease who were quarantined began a long social movement to recover their human rights and gain recognition as citizens. As a part of this movement, many of the associations of hospital residents began opening museums or archives designed and operated by survivors. The displays covered the history of Hansen's disease and the experience of life inside the quarantine facilities. Many of these independent museums still exist. In the case of Tama Zenshō-en, the Tokyo facility, the former residents' archives were reopened as the Prince Takamatsu Memorial Hansen's Disease Museum in 1993. The archive and museum were reestablished as the National Hansen's Disease Museum in 2007. A further change took place in April 2016, when the Ministry of Health, Labour and Welfare turned the administration of the museum over to the Nippon Foundation.

The survivor-run archives and museums provide a valuable counter-memorial and counter-narrative site that complicates state, medical and religious explanations of what it meant to experience the illness and its consequent social discrimination. As such, in addition to the national museum, the historical sites maintained in institutions such as Nagashima Aisei-en (Okayama), Kuriu Rakusen-en (Gunma) and Kikuchi Keifū-en (Kumamoto), among others, also deserve recognition and attention. At the same time, the fact that these historical sites are located in former quarantine facilities has meant that they are difficult to visit. People come specifically to conduct research or learn about the history of Hansen's disease. In a way, the stories of the survivors' experiences remain in quarantine and must be specifically sought out. The symbolic isolation of the stories of people who survived Hansen's disease remains full of meaning.

Oshima Seishō-en, a small public hospital located on an island in the Inland Sea of Japan, tells the history of the experience of Hansen's disease in a new way: in profound dialogue with the community around it. Oshima is part of the Setouchi International Art Festival (Setouchi Triennale), launched in 2010.

Under the Triennale project, residents trained community volunteers to share their history with visitors. Former dormitories have been refitted into areas for displaying art

\footnotetext{
${ }^{3}$ W. Anderson, Colonial Pathologies: American Tropical Medicine, Race, and Hygiene in the Philippines (Duke University Press, 2006). For more on medical conceptualizations of the bodies of sufferers in Japan, see K. Tanaka, ““They are not human:” Hansen's disease and medical responses to Hojo Tamio,” in D. Wittner and P. C. Brown (eds), Science, Technology, and Medicine in the Modern Japanese Empire (Routledge, 2016), $130-147$.

${ }^{4}$ W. Hirokawa, Kindai Nihon no Hansen-byō mondai to chiiki shakai [Modern Japan's Problem of Hansen's disease and local communities]. (Osaka daigaku shuppan-kai, 2010).
} 
and provide insight into daily life in the hospital, as in the exhibit series 'Tsunagari no Ie' (A Place of Connection). Photographs, books and archival material are displayed alongside the objects of daily life: radios, clothing, desks. Medical objects, such as walking sticks, artificial limbs and utensils adapted to accommodate the disabilities caused by the disease are also part of the exhibit, but are by no means its centre.

The exception, perhaps, is the exhibition of a cement autopsy table that was recovered from the ocean and displayed first in 2010 in front of 'GALLERY 15', which is part of the Tsunagari no Ie exhibit, this year featuring a boat exhibit entitled Umi no kodama (Echo of the Sea). Residents threw the table into the sea when the practice of performing autopsies on deceased residents was discontinued. ${ }^{5}$ Such autopsies were part of the medical control of their experience and the display of their bodies. For the 2010 exhibit, the table, cracked and covered in barnacles, was brought back out of the sea. It stands as a silent testimony to both the medical control of sufferers' lives and reclamation of their own narrative.

Oshima's contribution to the Triennale is quite rich, featuring work from the island's artists as well as art collaboration projects, such as Aozora Suizoku kan (Blue Sky Aquarium, Tashima Seizō), a comment on the ocean and the flow of time, and their connection to island life and the community around it. While such exhibits were made specially for the Triennale and some installations changing each year the exhibition is held, Oshima is also home to striking sculptural art, such as a conic stone monument of hope, Kaze no mai (Dance of the Wind), which was built by residents and volunteers as a memorial that carried the promise of a brighter future, as well as multiple stone statues and lanterns.

Finally, a restaurant and part of the Tsunagari no Ie series, Cafe Shiyoru, opened in a former dormitory with the aim of rediscovering and serving the food culture of Oshima it is staffed by volunteers and serves meals and sweets on Oshima-yaki, dishes made by residents with the clay from their island. ${ }^{6}$ The fruits and vegetables used in the dishes were also all grown on Oshima, all of which serve to deeply connect the café to the history and lived experience on the island. ${ }^{7}$

What makes Oshima's participation in the festival especially significant is the new way it displays the experience of Hansen's disease. By focusing on art as lived and living history, including objects from daily life and items created by the residents, the exhibits at Oshima reframe the illness experience and, more importantly, the place of survivors within the rest of the community. The nature of the Setouchi International Art Festival encourages island hopping, collaboration and dialogue. Visitors come to see the art, not to learn the history of Hansen's disease. Yet, when they come, the art they see leads them to think about the history of Hansen's disease in Japan and the experiences of the people who continue to live on the island. Art, not illness, brings guests to the island, creating new ties and connections. Art serves to restore ties to the community and create a history of the experience of Hansen's disease that moves beyond medicine and illness to include social reintegration and exchange, as social historian Abe Yasunari pointed out in his review of

\footnotetext{
5 "Hansen-byo no kanashi rekishi-kaibodai mae ni ireisai" [The Sad History of Hansen's Disease: A Memorial Ceremony Before the Autopsy Table]. Asahi shimbun (Kagawa prefecture), 22 July 2010, morning ed., +26.

6 "Ikiru kibō bugei ni takushita-Oshima Hansen-byō ryōyōjo no Yamashita-san" [Representing his hopes for living in pottery-Mr. Yamashita of Oshima Hansen's Disease Treatment Facility." Asahi Shimbun (Kagawa prefecture), 30 October 2010, morning edition, +31 .

7 A. Tasaka, "Shima kafe soto to tsunagaru" [An Island Cafe Connects to the Outside]. Yomiuri Shimbun (Kagawa Prefecture), 1 January 2012, morning edition, +35 .
} 
the 2013 exhibit. ${ }^{8}$ Such an exhibit makes for a worthwhile and thought-provoking trip for all those interested in the social history of medicine. ${ }^{9}$

Kathryn M. Tanaka

Otemae University, Japan

\footnotetext{
8 Abe, Yasunari. "Ato Kuritiku-Oshima, gendai ato, Setonai kokusai keijutsusai 2013" [Art Critique: Oshima, Modern Art, the Setouchi International Art Festival 2013]. Shiga Daigaku Keizai Gakubu Working Paper Series No. 195 (June 2013).

${ }^{9}$ The Art Festival is open at limited times in the spring, summer and autumn. Ferries from Takamatsu in Shikoku are available to take visitors island-hopping. Please confirm details on the Triennale website before planning your trip (http://setouchi-artfest.jp/en/about/).
} 